\title{
FORMS AND SOURCES OF CONFLICT IN NIGERIAN EDUCATIONAL SYSTEM: THE SEARCH FOR NIGERIAN PSYCHE
}

UDEME AKANINYENE UMO

(Received 2, July 2014; Revision Accepted 7, July 2014)

\begin{abstract}
Quite often, when mention is made of the Nigerian psyche, what readily comes to mind is the general attitude; or disposition of a vast majority of the citizenry and its desires or expectations of what the country should be like in order to facilitate the good life for the greater number of the populace. It also refers to the search for the mind set or soul of many Nigerians, what dominates the character, behaviour, thinking and conduct of the people and their interactions with the environment in which they live; or what many Nigerians seem to positively or negatively respond to. This paper examines forms and sources of conflicts in Nigerian educational system: The search for Nigerian psyche. This paper provides an insight into the Nigerian psyche, conflict, conflict actors and dynamics, Nested levels of conflict, analysis and the role of conflict analysis. The paper also examines forms and sources of conflicts in Nigerian Educational system, the need for modification of the Nigerian psyche, the Peace and Conflict Resolution in Nigeria, Resolving conflicts in Nigerian Educational system was proffered and Solutions/Recommendation was made using a ten-point strategy to bring about peaceful co-existence, simply because we have no other country except Nigeria.
\end{abstract}

\section{INTRODUCTION}

Since 1960 when Nigeria gained political independence, the country has had governments with low capacity for people-driven and inclusive development programming options. In many of these governments, decisions on the type, location and timing of a development intervention was a function of the whims and . caprices of policy makers who hardly understood the interface between development conflict, especially in the heterogeneous society of Nigeria. Numerous development projects were poorly conceived, and as a consequence, impacted negatively on the people. Needless to say that development challenges bordering on issues of human rights, academic, political and economic inclusion were part of the causal factors of the Nigerian civil war.

The history of inadequate planning capacity in Nigeria has had destabilizing effects on development at the micro (individual), meso (community), and macro (country) levels. In particular, the politics of the exploitation of oil, the control and appropriation of the huge revenues accruable to this sector, and the political economy of systemic. Corruption have remained the mainstay of the centrifugal forces that sustain conflict in the context of development. Development and conflict counts as part of an integrated picture of the social realities that shape Nigerians educational and political economy. Nigeria's choices of development must be moderated in such a way that they are sustainable and ultimately contribute to building peace and reducing the risk of violent conflict (IPCR 2003).

\section{THE NIGERIAN PSYCHE}

A psyche in Chambers Concise Dictionary refers to; the soul; spirit; mind; and generally, the principle of mental and emotional life, conscious and unconscious experiences (Chambers, 2004)

Udeme Akaninyene Umo, Department of Educational Foundations Guidance and Counselling, University of Calabar, Calabar 
Time and again, when one examines the Nigerian psyche as it concerns fundamental things, issues, matter and life of the nation state, the more one begins to reason that there is limit to which Nigeria and Nigerians as individuals, leaders and corporate body can continue to play game of bridge with the destiny of the country. The path to achieving good result and progress in whatever we are doing begins with full participation of the majority of citizens in problems of conflict identification, adopting and implementing appropriate strategies for solving the problem of negative and unacceptable traits in the Nigerian psyche. It calls for a collective effort/action to achieve attitudinal change that will facilitate the building of a nation that will enhance progress, unity and sustainable development (Ogbuagu, 2009). It is an avenue for permeating inculcation of basic discipline into all members of the society. Emphasis is often devoted to raising the dreams and hopes and hopes of the youths with regard to the vision of a fair, equitable, progressive and strong nation. In addition, many people advocate that there should be a well focused moral and national ethical rebirth. Nigerians need reorientation, sensitization, national rebirth, rebranding and true patriotic spirit to facilitate progress in Nigeria. Without doubt, the negative attributes in the society act as clogs in the wheel of progress in the nation's attempt to realize its full potentials.

\section{CONFLICT ACTORS \& DYNAMICS}

Conflict refers to a struggle involving two or more opposing forces. Conflict could be over resources, ideas, values, wishes, or deep-seated needs. It provides an opportunity for changing the status quo. Conflict as a social phenomenon becomes negative only when it is violent. A conflict could have a chain of causes - root causes, proximate causes and triggers and can be at various sages of escalation or deescalation. Here, we are looking at those forms and sources of conflicts in our educational system. The prevailing conflict actors here, are the individuals, the government, the polity, groups or institutions that are involved with a conflict directly or indirectly. They may be actors in the conflict at the primary, secondary, tertiary or shadow levels. Note also that, conflict actors definitely have some interest in the conflict and in its outcome (International Alert, 2003).

On December $8^{\text {th }}, 2011$ ASUU had embarked upon a three month strike action following the failure to compel the Federal Government Nigeria (FGN) to implement the agreement reached with the Union in October, 2009. The key areas on which the agreement was signed include: Funding requirements for revitalization of the Nigerian Universities, Federal Government Assistance to State Universities, Progressive increase of Annual Budgetary Allocation to Education to $26 \%$ between 2009 and 2020, Earned Academic Allowances, Amendment of the Pension/retirement Age of Academics of the Professorial cadre form 65 to 70 years, Transfer of Federal Government landed property to Universities, Setting up of Research and Development Units by Companies operating in Nigeria and Teaching and Research Equipment provision to our Laboratories and classrooms,

As a result of the failure by the Federal/State Government to implement fully the agreement reached with ASUU in October, 2009, and having exhausted all remedies in a democratic society, ASUU called on its members to go back to the trenches once again, by embarking on a total, comprehensive and indefinite strike beginning 12 midnight, on Sunday, 30 ${ }^{\text {th }}$ June, 2013.

The above conflict analysis between the FGN and ASUU shows the methodical study of the profile of a conflict, its root causes, actors and dynamics. The understanding gained from conflict analysis informs the response strategies in the form of programme/project interventions, it incorporates into development programming cycle for the purpose of building peace or mitigating violent conflict. It has become inevitable because FGN wants it so. The alternative to resisting is to do nothing and continue witnessing greater breach of trust, greater corruption, bad governance, further decay of the Nigerian Psyche and the University system. 


\section{NESTED LEVELS OF CONFLICT ANALYSIS}

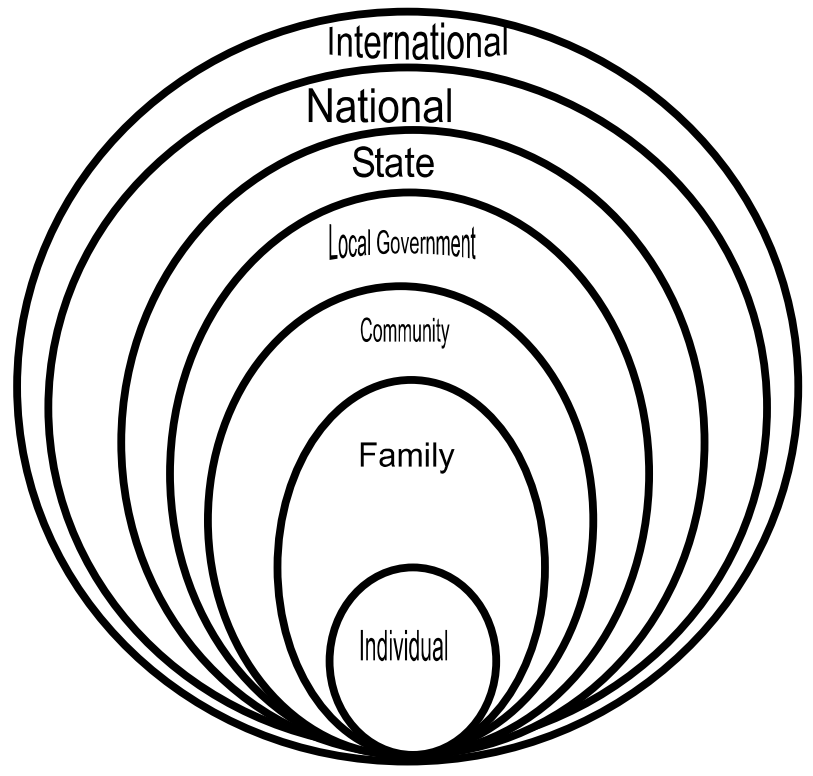

Figure 1: The 'Nested' Levels of conflict Analysis (IPCR, 2003)

The 'nested' levels of conflict analysis (above) help to explain the linkages across the hierarchy of social and political units, such that a conflict at one stratum could impact on another and vice versa. Thus, the 'nested' levels of analysis shows that the development programming cycle for a programme/project at any of these levels (individuals, family, community, local, state, national and international) has the potentials of multiplying pains (violent conflict) or gains (peace building) for the society (IPCR 2003). With genuine inculcation of True Nigerian psyche, whether the conflicts are resource based, educational, political, social, religions, identity or ethnic, their root causes can be linked to the specific context and the stage of development.

\section{FORMS AND SOURCES OF CONFLICTS IN NIGERIAN EDUCATIONAL SYSTEM}

Education is a potent key for transmitting knowledge and skills from generation to generation. It is a key for empowering the individual and the nation. The existence or emergence of conflicts in Nigerian educational system demands urgent attention and action in order to avert disastrous or undesirable consequences. To the perspective and analytical observer of the Nigerian scenario, there are many conflicts in the educational system which threatens its survival, development, relevance and utility.

Conflicts of curricular polices and implementation

The National Policy on education is replete with prescriptions on the curricular content and orientation for primary, secondary and different types of higher education under the 6-3-3-4 system and the universal Basic education system. There are problems, inconsistencies and unrealistic expectations inherent in the education system. Students are to study the language of the school locality and one major indigenous language. They are required to study French because Nigeria is surrounded by Franco - phone countries. Meanwhile, English remains our Lingua franca for education, government and business, causing confusion by requiring, and not insisting, that every SSCE candidate should take and pass a Nigerian language. 
There is also yawning gaps of conflict between curriculum policies and implementation on scientific, vocational and technical education, yet some subjects are not available, or there are no teachers for them, or there are no laboratories and workshops for practicals. The system encourage theoretical and rote learning, alternatives to practicals, objective/multiple choice questions and answers; and the use of "final examinations" for student assessment and certification. What happens to programs like social psychology; modern mathematics, population Education; HIVI AIDS Education; Citizenship Education, Teaching/Learning in mother Tongue, Environmental Education. Were these brain waves or Alice in wonderland experimental projects? (Nwagwu, 2003).

\section{Conflict of social phenomenon}

A very miserable social phenomenon occurs in Nigeria education. There exists a social craving for university degree from the public and this breeds an unprecedented number of citizens who acquired awarded doctorate degree titles across the social fabric of the citizenry. Even local chiefs and high spiritual heads took on doctoral and professorial titles awarded or bought, second chance afternoon schools sprang up, mothers, school drop-outs, sandwich programmes, part-time evening consultancies and even village adults, went back to primary or secondary schools for more education. The upsurge of Church/Christian based universities, colleges of Education with conflicting syllabus, unqualified / untrained teachers/lecturers, highly sensitive/indoctrinated rules, regulations opposing social views, discrimination and incredible leadership gained prominence. Nwachuku, 2007, opines that, Issues relating to indigenous or traditional education boldly emerged for open debates, such as (the apprenticeship system), the Muslim education, (the Qur'anic Schools), the Almajiri, the Church and State as stakeholders in the educational system separately or jointly, created lots of tension, conflicts and complexities in the education, social, economic and political sectors.

\section{Conflict of educational funding}

In Nigeria, education is a capital intensive, non-profit making social service. Technically, it is never "free" at any level. It must be paid, for, somehow, by somebody. The down turn of national economy let to cutting down funding, halting educational expansion and even crippled the provision of basic infrastructure, study materials and 'information and communication technology (ICT) equipments. In response, University education was mandated to create both funds and ideas, but, funding remains a nagging issue in Nigerian education, unresolved.

\section{Conflict with erosion of the Nigerian psyche}

Quite often, when mention is made of the 'Nigerian Psyche' what rightly comes to mind, as a social psychologist is the general attitude or disposition of a vast majority of the citizenry and its desires or expectations of what Nigeria should be like in order to facilitate good life for the greater number of the populace. It also connotes the search for the mind set/soul of many Nigerians; what dominate the character, behaviour, thinking and conduct of the people (Ogbuagu, 2009).

The erosion of moral integrity at the personal, social, corporate levels, and for the last two decades, Nigeria has witnessed an unprecedented display of moral decadence in all possible imaginable dimensions. The sacrificially, selfless services psyche of most Nigerians gave way to personal, selfish ambitions to amass wealth from public funds, is rather, depressing. Now a days, some parents expose their children to antisocial behaviour. Some purchase fake certificate for their children to gain admission into higher institutions of learning and some even pay huge sum of money to their children's teachers/lecturers to alter their failed grades (Uwe, Asuquo \& Ekuri, 2008). When parents fail to teach their children the necessary social/moral skills for successful interaction, such parents automatically leave their children vulnerable to learn inappropriate behaviours from those who would take advantage of them (Uwe \& Obot, 2000).

\section{Conflict of job satisfaction}

Umo (2003) opine that, the type of job a person does influence his socio-psychological well-being. It points to the fact that, if a person is engaged in a lowly paid job, his economic power will be low. The individual enters a job with the hope to gain his/her self - satisfaction which is an aspect of self - actualization. The individual operating in a socio - psychologically balanced organization will be able to fulfill his/her set goals, that of functioning maximally at work and at home. This is so because, if the work earns one the satisfaction he/she desires, they will be able 
to take care of their homes and meet their other needs (Umo, 2003).

In Nigerian education, honesty, excellence and hard work has been badly battered. Since degrees apparently could be sold and bought. The academic merchandise evolved large syndicates across the board which marketed JAMB/UME results, school certificates University degrees, professional courses and even National Youth Service Corps. We cannot curb students' examination malpractices, without curbing teacher grade malpractices, curb Certificate racketeering without curbing parents' patronage since parents fund the trade (Umo, 2003).

This will also apply to a situation where teachers/lecturers experiences poor work situation such as non-payment or irregular payment of salary, lack of promotion, lack of fringe benefits and lack of job security. A situation like these breed unhappiness, indiscipline discontent, depression, disobedience to constituted authority, extortion/ exploitation, absenteeism, sale of handouts, sexual harassment, membership of secret societies, rudeness, stealing and all sorts of professional misconduct exists among both teaching and non teaching staff at all levels of the Nigerian educational system (Umo, 2003) .

\section{Conflict of credible leadership}

Many keen observers of Nigeria in the past 53 years have concluded that, it is a country with amazing and fantastic endowments, which have been squandered and frittered away by a reckless, lawless, inept, quarrel- some and corrupt band of elite who are contemptuous of the requirements of good governance. There is a very high incidence of corruption in both the public and the private sectors, which are appropriately attributed to a profound crisis of leadership and governance. In the public sector in particular, there is no denying the fact that a band of short - sighted and greedy elite, politicians, both military and civilian have, within a few decades, created, nurtured and perpetuated the conversion of public treasury and national wealth for exceedingly private use (Jega, 2010).

Leadership in the education sector appears not to be the responsibility of anybody. There is too much passing of the buck. Federal government shifts blame of different conflicts to states, and the latter blame local Governments. Principals blame teachers, Vice Chancellors, Senate, and the University governing council blame Lecturers, and these in turn blame students and parents. The blames also revolve in reverse order. Needed, important and sometimes unpalatable decisions/ arguments about funding; approval of school programmes, weeding out of unproductive staff are delayed or shelved for want of courageous and committed leadership. Meanwhile, the education scenario continues to degenerate, some of our best teachers/Lecturers seek greener pastures abroad.

\section{Conflict of population/infrastructural facilities}

Nigeria, as we are aware, is made up of over 250 ethnic groups spread over 36 states and the FCT. Nigerians live in 774 local government councils in thousands of towns, communities and families. So ultimately Nigeria is a collection of millions of individuals - over 140 million of us and there is a high population growth rate. But the real conflict lies with uncertainties about the actual population figures. The population of students in our educational institutions is growing at geometric progression, while the expansion of infrastructural facilities is only growing at arithmetic progression.

There are phenomenal increases that creates shortage of everything, except students. Nwagwu (2003) opines that, there are students everywhere, but not the facilities to accommodate and educate them. Classroom, libraries, laboratories, workshops, hostels, Chairs, tables, water, electricity, school vehicles and equipments are all in short supply and militate against the successful implementation of education in Nigeria.

\section{Conflict of adolescence conduct}

Adolescence period includes mental, emotional, and social maturity as well as physical maturity. A stage in life cycle between 13 and 18 years of age, and extend to 21 years. Adolescence in G. Stanley Hall's views came to represent "storm and stress" period that reflected the unsettling turbulence of growth in modern societies.

As a matter of fact, most Nigerian students fall within these age brackets. Delinquency among adolescence in Nigerian education is a problem. Manifestations of increasing criminal acts, violence, vandalization of public and private property, suicide, bizarre acts, alcohol, drug abuse, unskilled use of dangerous tools, gross binge overeating, rapes, smoking, excessive aggression, gambling and 
rebellious against school rules, roles and regulations. Cultism and the activities of the cultists have been very disruptive, intimidating and criminal. Cultism has reared its ugly head, even in Secondary and tertiary institutions of learning. Academic work, security in and outside campuses, student management have all been adversely affected, and all these vices undermine the smooth running of the Nigerian educational system (Nwagwu, 2003).

\section{THE NEED FOR MODIFICATION OF THE NIGERIAN PSYCHE}

Nigerians need to remove the stumbling blocks on the path of progress, growth and development of the nation. They need to stop turning the hands of the nation's clock backward. The ethics of the present era, particularly among the political class, has not given rise to higher nationalistic consciousness and patriotism for the attainment of required national, socio-political and economic successes. There must be fundamental attitudinal and behavioural change on the part of both Nigerians and the Nigerian nation, in which a well focused moral and national ethical orientation should be showcased.

To bring about a Nigerian polity with acceptable psyche which is admirable to building, through collective effort and acceptance of a vast majority of the citizens. Nigerian system of governance at all the three tiers of government must be remodeled, making them truly democratic, responsible and responsive. For purposeful actions which meaningfully seek to erase negative tendencies and traits in individual and corporate lives for the nation to realize its full potentials. Simply, because we have no other country except Nigeria. It is also in our individual and collective interest to arrive at the Nigeria that we desire.

\section{PEACE AND CONFLICT RESOLUTION IN NIGERIAN EDUCATIONAL SYSTEM: (A TEN - POINT STRATEGY).}

The establishment of the Institute for Peace and Conflict Resolution (IPCR) in January, 2000 was a strategic response by the Federal Government of Nigeria towards tackling conflict disorders in the country. However, these initiative have short term impact; and development processes remain insensitive to conflict dynamics. To provide support for development in Nigeria, there is an urgent need for a paradigm shift in favour of conflict sensitive development programming (IPCR, 2003). In Nigeria, the need to mainstream peace building in development has arisen owing to the realisation that conflict disorders in the country continue to jeopardize the effort to combat poverty. I hereby present solutions to conflicts in Nigerian educational system with the following ten points:

* One of the most significant aspect of good governance is transparency and accountability. Therefore, we must seek to develop credible decent and competent leaders effectively and efficiently pilot democratic development.

- The Faith - Based Organizations (FBOs) have a great role to play, given their calling mass appeal, command of authority and following the moral context of their belief systems.

* New programmes, knowledge, novel instructional objectives and methods should be provided in order to correct present misconceptions about education, qualification, certification, employment, prospects, and survival.

* Formulation of a framework that is responsive to human rights-based, which will enable development planners and programmers bridge the gaps that account for much of the negative impact of development activities on peace and conflict in Nigeria.

* In order to facilitate the attainment of the desired objectives, Nigerians (can) be mobilized and motivated through the careful and consistent cultivation of a style of governance that places a premium on openness, transparency, accountability, popular participation, peaceful coexistence and leadership by example (Falade, Harbor \& Osofisan, 2004).

* Enabling environment should be created for productive teaching and learning by calling on the government, parents, faithbased organizations, appropriate legislation, and law enforcement agencies to rescue and support school authorities in all levels to maintain and ensure discipline.

* To excel in a changing world, we as individuals must be interested in life-long learning and acquisition of new survival skills, ethical standards, and international 
best practices in all spheres of human endeavours.

* For transformation to become a reality, we must always reward behaviours that support the academic dreams and punish those actions that work against it.

* Proper and intensive enlightenment and education of the citizenry as to their roles, obligations and responsibilities to governments and communities as citizens of a democratic polity.

* A heightened level of reorientation of the Nigerian psyche with emphasis on attitudinal change in both public and private sectors of the nation's life, be inculcated by reviewing our educational curriculum to reflect subjects as inclusive education, citizenry education, social psychology, and peace education. Nigeria would certainly be a better place to live when people learn to embrace peace and shun all acts of violence.

\section{CONCLUSIONS}

As mentioned earlier, this paper examined forms and sources of conflicts in Nigerian educational system; The search for Nigerian psyche. This various conflicts manifested themselves through curriculum policies and implementation, social phenomenon, educational funding, erosion of moral integrity, job satisfaction, credible leadership, population/infrastructural facilities and adolescence conduct to mention but few. The need for modification of Nigerian psyche was emphasized, for there must be a fundamental attitudinal change for peaceful co-existence. The recommendation was that, there is certainly critical need for reorientation, sensitization, national rebirth and rebranding in the educational system to provide major ways for developing the much desired true patriotic spirit or psyche of a large population of Nigerians in both public and private sectors, and to replace adverse attitude/behavior with acceptable social norms and values that are supportive of true democracy, justice, equity, respect for human rights, political and religious tolerance, cooperation, honesty and transparency for sustainable social and economic development in Nigeria.

\section{REFERENCES}

ASUU., 2013. Academic staff Union of University (ASUU) National secretariat strike Bulletin No 1. Resolutions of the National Executive Council (NEC) meeting of the ASUU, Held at The Olabisi Onabanjo University Ago - Iwoye, $29^{\text {th }}-30^{\text {th }}$ June.

Castren, E., 2005. Is mood Chemistry? Nat Rev. Neurosci 3:241-6 PMID 1573959.

Chambers., 2004. Chambers concise dictionary by Chambers Harrop Publisher Ltd, July, 2004 Edition, Edingburgh, Scotland.

Falade, J. B., Harbor, S and Osofisan, W., 2004. Elements of Projection Design: An Analysis of NGO projects for strengthening Electoral Process projects in Nigeria, Lagos; UNDP.

Fasokun, T. O., 2004. culture of Peace, Peace education and Adult Education: Issues and Perspectives. A Lead paper Presented at the Nigeria National Council for Adult Education at Department of Adult Education, university of Ibadan, 21 - 22 september.

Jega, A. M., 2010. Developing Credible Leaders: The Role of Faith -Based Organizations, Text of a Public Lecture, organized by ECKANKAR, Nigeria, at the women Development Cente, Abuja September $23^{\text {rd }}$

IPCR., 2003. The Strategic Conflict Assessment: Zonal and consolidated Report, Abuja.

Nwagwu, N. A., 2003. Crisis in the Nigerian Educational System. A paper presentation at the World Council for Curriculum and Instruction (WCCl) Nigerian chapter $2^{\text {nd }}$ Biennial Lecture, October, $28^{\text {th }}$ at the University of Lagos, Akoka, Lagos.

Nwachuku, D. N., 2007. Education and Humanity: Nigerian Renaissance and Millennium Pedagogical Shift in Paradigms. $39^{\text {th }}$ Inaugural Lecture of the University of Calabar, Calabar Nigeria, October $10^{\text {th }}$ University of Calabar press. 
Nwolise O. B. C., 2003. War Marking, Peace Making and Conflict Resolution in African. A Guide to Peace Education and Peace Promotion Strategies in African: (eds) Hakeem B. H; Nwolise O. B.C and Day O. Volume 7. The Nigerian Approach. Africa Refugee foundation, Lagos.

Ogbuagu, C., 2009. The Search for Nigerian Psyche. A paper presentation at the Nigerian Society for Psychical Research (NSPR) $3^{\text {rd }}$ National conference, held at the Chinua Achebe Lecture Theatre, Michael Okpara University of Agriculture, Umudika, Abia State, Nigeria, November $11^{\text {th }}$

Oghenekohowo, J. E., 2003. The Cost-Benefit Analysis of Conflict Resolution and Management in a Pluralist Nigeria Society. The Nigerian Journal of Industrial Education and Labour Relation Vol. 6, No 1 \& July - December.
Quisumbling, L. R., 2000. Educating Young Children for a Peaceful World. Second World Forum on Early Child Care and Education, Singapore. 16 - 19, May.

Umo, U. A., 2003. Socio - Economic Determinants of Depression Among Public Servants in Cross River State, Nigeria Master of Education Degree Thesis in Educational Psychology University of Calabar, Calabar, Nigeria.

Uwe, E. A., Asuquo, P. N and Ekuri E. E., 2004. African Women and Vulnerability to HIVIAIDs. Implication on female related cultural practices. A paper presented at the an African Anthropological Association conference, Legon, Ghana, August $2^{\text {nd }}-6^{\text {th }}$

Uwe, E. A and Obot, A. E., 2000. Marriage Counselling: Issues and solutions. Pyramid publishers, Calabar. 